Ann. Biol. anim. Bioch. Biophys., 1979, 19 (3 A), 625-635.

\title{
Influence of oral MCT or LCT load on glycemia in Wistar and Zucker rats and in guinea pigs
}

\author{
par A. BACH, A. WERYHA, H. SCHIRARDIN \\ Laboratoire de la Clinique Médicale A, Hôpital Civil, \\ 67091 Strasbourg Cedex, France.
}

\begin{abstract}
Summary. An oral load of medium-chain triglycerides (MCT) (containing fatty acids ranging from $C_{6}$ to $C_{12}$ ) in non-fasting Wistar rats induced a decrease in plasma levels of lactate, pyruvate and glucose. These variations were more marked in females than in males of the same age, and were a direct function of the MCT load. Post-MCT hypoglycemia was also observed in previously fasting rats and was definitely determined in guinea pigs, but was not proved in genetically obese Zucker rats. This hypoglycemia was preceded by a slight increase in the plasma insulin level. Long-chain triglycerides (LCT) (containing fatty acids over $\mathrm{C}_{12}$ ) had no effects on the factors studied. It therefore seemed that the large increase in ketone-body levels caused by MCT load induced an increase in insulin secretion, which in turn caused the observed post-MCT hypoglycemia.
\end{abstract}

\section{Introduction.}

Hypoglycemia induced by a load of medium-chain triglycerides (MCT) (containing fatty acids from $\mathrm{C}_{6}$ to $\mathrm{C}_{12}$ ) has already been reported in humans (Tamir et al., 1968 ; Pi-Sunyer, Hashim and Van Itallie, 1969 ; Bach, 1970) as well as in dogs (Bach et al., 1974), and recently in rats (Yeh and Zee, 1976). We have previously demonstrated the influence of MCT on ketonemia on rats (Bach ef al., 1977a). The present paper reports the effect of certain factors - the amount of fat given, sex, and replacement by long-chain triglycerides (LCT) containing fatty acids over $\mathrm{C}_{12}$ - on hypoglycemia after MCT load. Another object of this study was to defermine if post-MCT hypoglycemia depended on initial glycemia. Therefore, on one hand, we obtained a low initial glycemia by using fasted animals, and on the other, we studied obese Zucker rats which are hyperglycemic animals (Bach, Baver and Schirardin, 1977b). We also attempted to define this phenomenon in guinea pigs.

\section{Material and methods.}

Animals.

We used male Wistar rats (CESAL, Vigneul-sous-Montmedy) and genetically obese Zucker rats (Zucker and Zucker, 1961) (CSEAL, CNRS, Orléans). In one case, 
we compared female and male Wistar rats of the same age. Male albino guinea pigs (CESAL, Vigneul-sous-Montmedy) were also used in a series of experiments.

All animals were fed a stock diet ad libitum (UAR, Villemoison-sur-Orge). The rats were given tap water to drink, and the guinea pigs an ascorbic acid solution. The animals had access to food until administration of the fat emulsion. In the case of unfed animals, food was withheld rats for 15 or 40 hrs before the fat load.

- Fats.

Two types of fat were given : MCT $\left(C_{8: 0}, 50.5\right.$ p.100; $C_{10: 0}, 48.0$ p. $100 ; C_{12: 0}$, 1.0 p. 100) and LCT in the form of peanut oil (mainly $C_{16: 0}, 11.4$ p. $100 ; C_{18: 0}, 3.0$ p. 100 ; $C_{18: 1}, 46.8$ p. $100 ; C_{18: 2}, 31.4$ p. $100 ; C_{22: 0}, 3.3$ p. 100). $\mathrm{NaCl}$.

The fat in the controls was replaced with an equivalent weight of $154 \mathrm{mmol} / \mathrm{l}$

\section{- Experimental design.}

1. Unanesthetized animals. - To distinguish the influence of the fat load itself from that of stress due to handling and to the introduction of the stomach tube, we used control rats at each sampling time.

Since it was materially impossible to conduct a large simultaneous series using a factorial design and strictly identical animals, we adopted a plan with a short series of experiments repeated for several consecutive days. Paired animals (one for each parameter studied) were used in each series. Based on the results obtained in the first time-study experiment and on practical manipulative consideration, we chose $35 \mathrm{~min}$. after fat ingestion as the sampling time for all experiments.

At the beginning of the experiments, the unanesthetized rats were given $1 \mathrm{ml}$ of fat emulsion ( $1.5 \mathrm{~g}$ fat, $3.5 \mathrm{~g} 154 \mathrm{mmol} / \mathrm{I} \mathrm{NaCl}, 0.05 \mathrm{~g}$ Tween 60 ) by stomach tube ; this dose was equivalent to $0.292 \mathrm{~g}$ of pure MCT per rat.

To study the effect on hypoglycemia of the amount of fat given, the ratio of fat to $154 \mathrm{mmol} / \mathrm{l} \mathrm{NaCl}$ in the emulsion was varied so that $1 \mathrm{ml}$ of emulsion contained 0 , $0.119,0.292,0.348$ or $0.460 \mathrm{~g}$ of MCT.

The rats were stunned and decapitated for sampling. The blood was partially collected into cold $0.5 \mathrm{~mol} / \mathrm{l}, \mathrm{HClO}_{4}$ and partially over heparin (Choay, Paris). In the latter case, the sample was immediately centrifuged and the plasma stored at $-20^{\circ} \mathrm{C}$ for insulin assay. The blood $/ \mathrm{HClO}_{4}(\mathrm{w} / \mathrm{v})$ ratio in the mixture of blood and perchloric acid was adjusted to $3 / 1$ with $0.5 \mathrm{~mol} / 1 \mathrm{HClO}_{4}$. After centrifugation the supernatant was neutralized with $7 \mathrm{~mol} / \mathrm{KOH}$ and powdered $\mathrm{HKCO}_{3}$ and cooled.

2. Anesthetized rats. - To sample portal blood, we did an experimental series using non-fasting Wistar rats anesthetized with pentobarbital $(0.10 \mathrm{ml} \mathrm{Nembutal} / 100 \mathrm{~g}$ body weight, given intraperitoneally). One $\mathrm{ml}$ of emulsion $(1.5 \mathrm{~g}$ fat, $3.5 \mathrm{~g} 154 \mathrm{mmol} / \mathrm{l}$ $\mathrm{NaCl}, 0.05 \mathrm{~g}$ Cremophor EL (BASF Ag, Ludwigshafen am Rhein, W. Germany) was perfused into the proximal duodenum at a rate of $0.075 \mathrm{ml} / \mathrm{min}$. over $13 \mathrm{~min} .20 \mathrm{sec}$. The portal vein was exposed as described by Hems ef al. (1966). Thirty minutes after the start of the perfusion, blood samples were collected in cooled syringes by orienting 
the needle against the direction of blood flow. The 25 gauge needle was bent into a $U$ shape (Krebs and Perkins, 1970). About $1 \mathrm{ml}$ of blood was collected over EDTA supplemented with $750 \mathrm{KI}$ units of aprotinin (Novo Industrie Pharmaceutique, Paris). After centrifugation, part of the plasma was frozen for insulin assay, and the rest was used for assay of non-esterified fatty acids.

\section{- Analytical methods.}

The neutralized extract was enzymatically assayed for glucose (Bergmeyer ef al., 1970), lactate (Hohorst, 1970), pyruvate (Czok and Lamprecht, 1970) and ketone bodies (Williamson, Mellanby and Krebs, 1962). Non-esterified fatty acids (NEFA) were assayed by the method of Soloni and Sardina (1973), permitting determination of medium-chain fatty acids.

Plasma insulin (immunoreactive insulin, IRI) was assayed by single-antibody radioimmunoassay (insulin antibody raised on the guinea-pig) with separation of free insulin on charcoal-dextran (CEA-IRE-SORIN assay kit). Rat insulin (Novo Industrie Pharmaceutique, Paris) was used as a standard. Insulinemia was expressed in $\mathrm{ng}$ per $\mathrm{ml}$ of plasma ( $1 \mathrm{ng}$ is roughly equivalent to $20.7 \mu \mathrm{U}$ ).

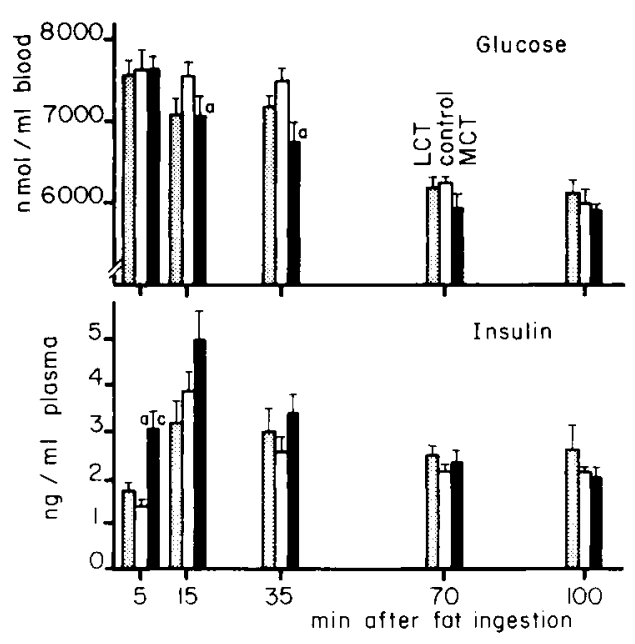

FIG. 1.

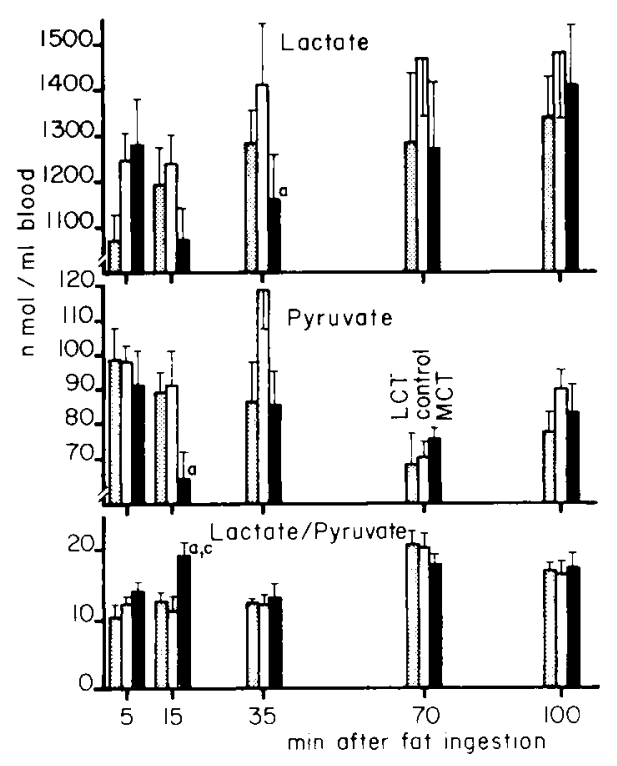

FIG. 2.

FIGS. 1 and 2. - Changes in plasma insulin and in whole blood glucose, lactate, pyruvate, and the lactate/ pyruvate ratio after an oral fot lood in non-fasting Wistor rats. Weight of rats : $261 \pm 2 \mathrm{~g}(\mathrm{n}=114)$. The load in the form of $1 \mathrm{ml}$ emulsion $(1.5 \mathrm{~g}$ fat, $3.5 \mathrm{~g} 154 \mathrm{mmol} / \mathrm{I} \mathrm{NaCl}, 0.05 \mathrm{~g}$ Tween 60) was given at time 0 . Results are expressed as means $\pm \operatorname{SEM}(n=8$ at 5,70 and $100 \mathrm{~min}$. ; $n=7$ at 5,35 , and $70 \mathrm{~min}$.). Vertical lines represent 1 SEM. Paired differences tested by analysis of variance are indicated by $a$ or $c$ when significantly different $(p<0,05): a, M C T$ vs. Control ; $c$, MCT vs. LCT ; no letter, non-significant difference. 
- Statistical analysis.

Results were expressed as means $上$ SEM. Taking account of the chosen experimental model, paired differences were tested by analysis of variance using the 5 p. 100 level for statistical significance.

Percentages of variation given in the test were calculated from the means of the various results.

\section{Results.}

For the sake of clarity, the variations in plasma levels of triglycerides, nonesterified fatty acids, and ketone bodies during some of the experiments reported here have been published elsewhere (Bach et al., 1977a).

Time-dependent variation of glucose, lactate, pyruvate and insulin. - Figures 1 and 2 show that MCT load caused a decrease in blood concentrations of glucose, lactate, and pyruvate as compared to control rats. MCT also increased the lactate/pyruvate ratio. There was an increase in IRI $5 \mathrm{~min}$. after ingestion. Although the IRI values were higher after $15 \mathrm{~min}$. than after 5 , the difference was not significant.

LCT, in contrast, had no effect on any of these factors.

Influence of increasing MCT load. - The decrease in glucose, lactate, and pyruvate blood levels was proportional to the amount of fat given. Figure 3 shows the linear relation between the amount of MCT administered and the blood levels of these three substances. The slopes of the three regression lines differ significantly from 0.

At $35 \mathrm{~min}$. the plasma level of IRI remained roughly the same regardless of the amount of fat given.
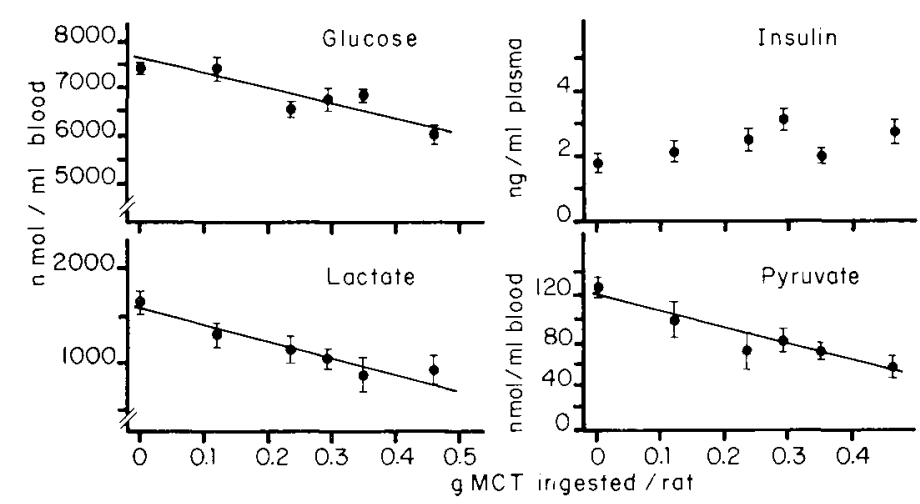

FIG. 3. - Effect of the amount of MCT administered to non-fasting Wistar rats. Weight of rats : $241 \pm 4 \mathrm{~g}$ $(n=32)$. The rats were killed $35 \mathrm{~min}$. after the ingestion of $1 \mathrm{ml}$ of MCT emulsion. The ratio of fat to $154 \mathrm{mmol} / \mathrm{I} \mathrm{NaCl}$ in the emulsion was varied, so that $1 \mathrm{ml}$ of emulsion contained $0,0.119$ $0.235,0.292,0.348$ or $0.460 \mathrm{~g}$ of pure MCT. Results are expressed as means $\pm \operatorname{SEM}(n=5$, except for the values 0.292 , where $n=7$ ). 
Influence of sex. - In response to a MCT load, levels of glucose, lactate and pyruvate decreased more in females than in males of the same age (table 1).

TABLE 1

Sex difference in metabolic changes after MCT load in non-fasting Wisfar rats

\begin{tabular}{|c|c|c|c|c|c|}
\hline & \multirow[b]{2}{*}{$\begin{array}{c}\text { Body weight } \\
\mathrm{g}\end{array}$} & \multicolumn{4}{|c|}{ Metabolic changes (p. 100) } \\
\hline & & Lactate & Pyruvate & $\begin{array}{l}\text { Lactate/ } \\
\text { Pyruvate }\end{array}$ & Glucose \\
\hline $\begin{array}{l}\text { Males } \ldots \ldots \ldots \ldots \ldots \\
\text { Females } \ldots \ldots \ldots \ldots \ldots\end{array}$ & $\begin{array}{c}239 \pm 5 \\
191 \pm 4 \\
b\end{array}$ & $\begin{array}{c}-23 \pm 7 \\
a \\
-38 \pm 3 \\
a\end{array}$ & $\begin{array}{c}-26 \pm 9 \\
-58 \pm 5 \\
a, b\end{array}$ & $\begin{array}{l}+27 \pm 6 \\
+41 \pm 18\end{array}$ & $\begin{array}{c}-9 \pm 3 \\
a \\
-14 \pm 3 \\
a, b\end{array}$ \\
\hline $\begin{array}{l}\text { The rats were killec } \\
\mathrm{NaCl}, 0.05 \mathrm{~g} \text { Tween } 60 \text { ). } \\
\text { and the liver weight } / 10 \\
\text { ( } 8 \text { controls }+8 \mathrm{MCT}) . \mathrm{N} \\
\text { ponding value in contro } \\
\text { variance are indicated } \\
\text { (males or females); } \mathrm{b} \text {, }\end{array}$ & $\begin{array}{l}\text { in. after inge } \\
\text { its are expres } \\
\text { at were cal } \\
\text { lic changes } \\
\text { the same sex } \\
r \text { b when sig } \\
\text { vs. females. }\end{array}$ & $\begin{array}{l}\text { of } 1 \mathrm{ml} \text { of } \\
\text { as means } \\
\text { ed from fic } \\
\text { MCT were } \\
\text { hout fat loc } \\
\text { antly differe }\end{array}$ & $\begin{array}{l}\text { CT emulsion } \\
\text { SEM. The ave } \\
\text { res obtained } \\
\text { lculated as } \dagger \\
\text { Paired diffe } \\
\text { (p }<0.05) \text {; }\end{array}$ & $\begin{array}{l}.5 \mathrm{~g} \mathrm{MCT}, 3 . \\
\text { age weight } \\
\text { in } 16 \text { anima } \\
\text { e percentage } \\
\text { ences tested } \\
\text { MCT rats }\end{array}$ & $\begin{array}{l}154 \mathrm{mmol} / \mathrm{l} \\
\text { he animals } \\
\text { of each sex } \\
\text { the corres- } \\
\text { analysis of } \\
\text { antrol rats }\end{array}$ \\
\hline
\end{tabular}

Influence of fasting. - An MCT load decreased blood glucose in fasting animals as compared to the control rats in the same physiological state (fig. 4). LCT had no effect. A fat load had no effect on lactate, pyruvate, and lactate/pyruvate ratio, beyond that induced by fasting.
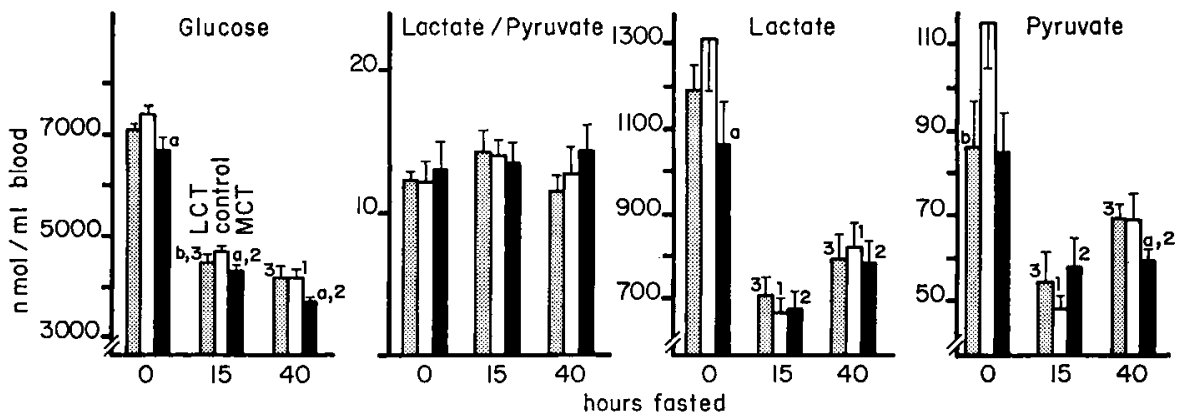

FIG. 4. - Influence of a previous fast on blood glucose level after a fot load in Wistar rats. Weight of rats : fasting controls $(0 \mathrm{~h}), 243 \pm 2 \mathrm{~g}$; after fasting $15 \mathrm{hrs} .227 \pm 2 \mathrm{~g}(-6 \mathrm{p} .100)$; after fasting 40 hrs., $213 \pm 3 \mathrm{~g}(-12 \mathrm{p} .100)$. Rats were killed $35 \mathrm{~min}$. after ingestion of $1 \mathrm{ml}$ of fat emulsion $(1.5 \mathrm{~g} \mathrm{fat}, 3.5 \mathrm{~g} 154 \mathrm{mmol} / \mathrm{l} \mathrm{NaCl}, 0.05 \mathrm{~g}$ Tween 60). Results are expressed as means \pm SEM ( $n=7$ at $0 \mathrm{~h}, n=8$ at $15 \mathrm{hrs}$ and $40 \mathrm{hrs}$ of fasting). Vertical lines represent 1 SEM. Results obtained after the fat load were compared with those obtained in controls in the same nutritional state. Paired differences tested by analysis of variance are indicated by $a, 1,2$ or 3 when significantly different $(p<0.05)$ : $a$, MCT vs. Control ; 1 , Control 15 or 40 hrs. fasting vs. Control non-fasting ; 2, MCT 15 or 40 hrs. fasting vs. MCT non-fasting ; 3, LCT 15 or $40 \mathrm{hrs}$. fasting vs. LCT non-fasting. 
Genetically obese Zucker rats. - Lactate, pyruvate and the lactate/pyruvate ratio (table 2) generally seemed higher, and glucose lower, in the non-obese Zucker rats than in the obese animals. Fat load did not appear to affect the various levels studied.

Guinea pigs. - An MCT load induced marked hyperketonemia, slight hypoglycemia ( 9 p. 100) and an increase of lactate in guinea pigs (table 3 ). Insulin could not be assayed, since we had only guinea-pig antibody.

TABLE 2

Metabolic changes after an oral fat load in non-fasting genetically obese Zucker rats

\begin{tabular}{|c|c|c|c|c|c|c|c|}
\hline Rats & $\begin{array}{l}\text { Body } \\
\text { weight } \\
\text { (g) }\end{array}$ & $\begin{array}{l}\text { Liver weight/ } \\
100 \mathrm{~g} \text { body } \\
\text { weight (g) }\end{array}$ & Fats & $\begin{array}{c}\text { Lactate } \\
(\mathrm{nmol} / \mathrm{ml})\end{array}$ & $\begin{array}{l}\text { Pyruvate } \\
(\mathrm{nmol} / \mathrm{ml})\end{array}$ & $\begin{array}{l}\text { Lactate/ } \\
\text { pyruvate }\end{array}$ & $\begin{array}{c}\text { Glucose } \\
(\mathrm{nmol} / \mathrm{ml})\end{array}$ \\
\hline $\begin{array}{l}\text { Non-obese ... } \\
(\mathrm{Fa} /-)\end{array}$ & $241 \pm 4$ & $4.2 \pm 0.1$ & $\begin{array}{l}\text { Control } \\
\text { MCT } \\
\text { LCT }\end{array}$ & $\begin{array}{r}1356 \pm 258 \\
901 \pm 71 \\
\pm c \\
1742 \pm 279\end{array}$ & $\begin{array}{l}97 \pm 10 \\
69 \pm 9 \\
99 \pm 15\end{array}$ & $\begin{array}{l}13.8 \pm 1.5 \\
14.4 \pm 1.5 \\
16,1 \pm 1.7\end{array}$ & $\begin{array}{l}5761 \pm 294 \\
5166 \pm 243 \\
5367 \pm 248\end{array}$ \\
\hline $\begin{array}{l}\text { Obese } \\
(\mathrm{fa} / \mathrm{fa})\end{array}$ & $349 \pm 7$ & $4.6 \pm 0.1$ & $\begin{array}{l}\text { Control } \\
\text { MCT } \\
\text { LCT }\end{array}$ & $\begin{array}{c}1441 \pm 156 \\
1308 \pm 129 \\
\frac{2}{1363 \pm 67}\end{array}$ & $\begin{array}{l}152 \pm 9 \\
118 \pm 16 \\
118 \frac{2}{2} \\
127 \frac{ \pm}{3} 10\end{array}$ & $\begin{array}{r}9.8 \pm 0.9 \\
\frac{1}{1} \\
11.9 \pm 0.9 \\
a \\
11.3 \pm 0.9\end{array}$ & $\begin{array}{c}6169 \pm 235 \\
1 \\
5500 \pm 286 \\
2 \\
5671 \pm 341\end{array}$ \\
\hline
\end{tabular}

Rats were killed $35 \mathrm{~min}$. after ingestion of $1 \mathrm{ml}$ fat emulsion $(1.5 \mathrm{~g}$ fat, $3.5 \mathrm{~g} 154 \mathrm{mmol} / \mathrm{l} \mathrm{NaCl}, 0.05 \mathrm{~g}$ Tween 60). Results are expressed as means \pm SEM $(n=8)$. The average weight of the rats and the liver weight $/ 100 \mathrm{~g}$ rat were calculated from figures obtained from 24 animals in each group. Paired differences tested by analysis of variance are indicated by $a, c, 1,2$ or 3 when significantly different $(p<0.05): a$ MCT vs. Control ; c, MCT vs. LCT ; 1 , obese Control vs. non-obese Control ; 2 , obese MCT vs. non-obese MCT, 3, obese LCT vs. non-obese LCT.

TABLE 3

Voriations of blood levels of some substances after a single fat load in guinea pigs

\begin{tabular}{|c|c|c|c|c|c|c|}
\hline Guinea pigs & $\begin{array}{c}\text { NEFA } \\
(\mathrm{nmol} / \mathrm{ml})\end{array}$ & $\begin{array}{l}\text { Ketone bodies } \\
(\mathrm{nmol} / \mathrm{ml})\end{array}$ & $\begin{array}{l}\text { Lactate } \\
(\mathrm{nmol} / \mathrm{ml})\end{array}$ & $\begin{array}{c}\text { Pyruvate } \\
(\text { nmol } / \mathrm{ml})\end{array}$ & $\begin{array}{l}\text { Lactate/ } \\
\text { Pyruvate }\end{array}$ & $\begin{array}{l}\text { Glucose } \\
(\mathrm{nmol} / \mathrm{ml})\end{array}$ \\
\hline $\begin{array}{l}\text { Control } \ldots \ldots \ldots \ldots \\
\text { MCT } \ldots \ldots \ldots \ldots\end{array}$ & $\begin{array}{l}106 \pm 17 \\
127 \pm 4\end{array}$ & $\begin{array}{c}9.0 \pm 0.4 \\
87.8 \pm 7.8 \\
a, c\end{array}$ & $\begin{array}{r}919 \pm 77 \\
1424 \pm 199 \\
\text { a, c }\end{array}$ & $\begin{array}{l}59 \pm 7 \\
65 \pm 7\end{array}$ & $\begin{array}{c}14.1 \pm 1.7 \\
25.0 \pm 2.4 \\
a, c\end{array}$ & $\begin{array}{c}7070 \pm 170 \\
6440 \pm 230 \\
a\end{array}$ \\
\hline LCT & $105 \pm 10$ & $\underset{b}{16.8 \pm} 3.2$ & $679 \pm 63$ & $59 \pm 9$ & $13.2 \pm 12.0$ & $6740 \pm 240$ \\
\hline
\end{tabular}

Guinea pigs $(288 \pm 6 \mathrm{~g}$ ) were killed $35 \mathrm{~min}$. after ingestion of $1 \mathrm{ml}$ fat emulsion $(1.5 \mathrm{~g} \mathrm{fat}, 3.5 \mathrm{~g} 154 \mathrm{mmol} / \mathrm{l}$ $\mathrm{NaCl}, 0.05 \mathrm{~g}$ Tween 60$)$. Results are expressed as means \pm SEM $(n=8$ except for glucose, where $n=10)$. Paired differences tested by analysis of variance are indicated by $a, b$ or $c$ when significantly different $(p<0.05)$ : a, MCT vs. Control ; b, LCT vs. Control ; c, MCT vs. LCT. Ketone bodies, sum of $\beta$-hydroxybutyrate + acetoacetate. 
Changes in portal blood insulinemia. - Duodenal perfusion of MCT led to a marked increase of NEFA and IRI levels in portal blood (table 4). When LCT were given instead of MCT, neither factor was affected.

TABLE 4

Portal plasma changes of non-esterified fatty acids (NEFA) and insulin (IRI) after a fat load in anesthetized Wistar rats

\begin{tabular}{ccc}
\hline Rats & $\begin{array}{c}\text { NEFA } \\
(\mathrm{nmol} / \mathrm{ml})\end{array}$ & $\begin{array}{c}\text { IRI } \\
(\mathrm{ng} / \mathrm{ml})\end{array}$ \\
\hline Control $\ldots \ldots \ldots$ & $85 \pm 10$ & $6.6 \pm 0.6$ \\
MCT $\ldots \ldots \ldots \ldots$ & $\begin{array}{c}451 \pm 86 \\
\mathrm{a}, \mathrm{c}\end{array}$ & $\begin{array}{c}9.7 \pm 0.7 \\
\mathrm{a}, \mathrm{c}\end{array}$ \\
LCT $\ldots \ldots \ldots \ldots$ & $78 \pm 7$ & $5.5 \pm 0.3$
\end{tabular}

Non-fasting rats $(254 \pm 10 \mathrm{~g})$ were anesthetized with $0.10 \mathrm{ml} \mathrm{Nembutal} / 100 \mathrm{~g}$ body weight. One $\mathrm{ml}$ of fat emulsion ( $1.5 \mathrm{~g}$ fat, $3.5 \mathrm{~g} 154 \mathrm{nmol} / \mathrm{I} \mathrm{NaCl}, 0.05 \mathrm{~g}$ Cremophor) was perfused into the proximal duodenum at a rate of $0.075 \mathrm{ml}$ per min. over $13 \mathrm{~min}$. $20 \mathrm{sec}$. Portal blood was withdrawn $30 \mathrm{~min}$. after the start of perfusion. Results are expressed as means $\_$SEM $(n=8$ for NEFA $; n=9$ for IRI). Paired differences tested by analysis of variance are indicated by a or $\mathrm{c}$ when significantly different $(p<0.05) ; a$, MCT vs. Control ; $c$, MCT vs. LCT.

\section{Discussion.}

Blood glucose.

- Effect of MCT. - Hypoglycemia resulting from MCT load has been reported in fasting humans upon MCT ingestion (Bach, 1970) and in fasting dogs perfused with such fats (Bach et al., 1974). These results were confirmed by the drop in glucose level when octanoate was perfused in dogs (Sanbar et al., 1965, 1967 ; Campbell et al., 1966). Recently, Yeh and Zee (1976) reported similar hypoglycemia in non-fasting rats ingesting $10 \mathrm{ml}$ of pure MCT per $\mathrm{kg}$ of body weight. We obtained the same result with a physiological load 7 to 8 times less than that of Yeh and Zee.

Figure 1 shows that post-MCT hypoglycemia was rapidly established : while there was no effect after $5 \mathrm{~min}$, it was well established after 15 . Taking into account the variations observed for the various times studied, the minimum could be estimated to occur some $20 \mathrm{~min}$. after ingestion of this fat. On the whole, the observed variation remained slight : -7 p. 100 after $15 \mathrm{~min},-10$ p. 100 after $35 \mathrm{~min}$. This may explain why it was overlooked by some authors (Greenberger, Tzagournis and Graves, 1968 ; McCullough ef al., 1971), who were studying it in humans.

The glucose level dropped from $7500 \mathrm{nmol} / \mathrm{ml}$ blood in fed rats to 4.810 and $4.310 \mathrm{nmol} / \mathrm{ml}$ blood in rats fasting for 15 and $40 \mathrm{hrs}$, respectively (fig. 4). An MCT load produced an additional drop in glucose level, which was similar in all cases ( $-10,-8$, and -12 p. 100, respectively, as compared with control rats). In Zucker rats, we could not show that the drop in glycemia after an MCT load was significant in either the non-obese normoglycemic rats or the slightly hyperglycemic obese 
ones. In the latter, this was probably due to the recognized insulin resistance of obese animals (York, Steinke and Bray, 1972).

Hypoglycemia increased when the oral MCT load was increased from 0 to $0.460 \mathrm{~g}$ per Wistar rat. There was an inverse linear relation between the amount of MCT given and the glucose blood level (fig. 3). At $10 \mathrm{ml} \mathrm{MCT} \mathrm{per} \mathrm{kg}$ body weight, hypoglycemia was 25 to 40 p. 100 (Yeh and Zee, 1976). Our results obtained in rats confirmed those previously obtained in dogs perfused with increasing MCT loads (Guisard et al., 1972).

Table 1 indicates that after MCT ingestion, glucose level fell slightly less in male Wistar rats than in females of the same age ( -9 vs. -14 p. 100). We believe that this observation might be related to the finding that female organisms are more sensitive to fasting and show more pronounced hypoglycemia than male organisms (Deuel and Davis, 1942 ; Merimee and Fineberg, 1973).

Finally, post-MCT hypoglycemia ( -9 p. 100) was also found in guinea pigs (table 3).

- Effect of LCT. - LCT never induced hypoglycemia when used in place of MCT. This results agreed with that of Yeh and Zee (1976), who could not induce a drop in blood glucose levels with a very large LCT load.

Some other authors have obtained relevant results. Coran, Cryer and Horwitz (1972) found no hypoglycemia when fasting baboons were perfused with $0.4 \mathrm{~g} / \mathrm{kg}$ body weight of Intralipid (triglycerides with long-chain fatty acids). Pi-Sunyer, Hashim and Van Itallie (1969) reported a slight hypoglycemia in fasting humans after ingestion of $1 \mathrm{~g}$ corn oil/kg body weight. Finally, Greenough, Crespin and Steinberg (1967) and Bates, Linn and Huen (1976) reported hypoglycemia in fasting dogs and rats, respectively, after rapid perfusion of long-chain fatty acids.

The two latter results suggest that the observed hypoglycemia was not characteristic of MCT, but might instead be the consequence of a massive and rapid hepatic oxidation of fatty acids, whatever their lenght. This possibility cannot be definitely ruled out, although the absence of hypoglycemia in fasting rats given LCT tends to argue against it.

\section{Blood lactate and pyruvate.}

Concomitant with the drop in blood glucose after an MCT load, the levels of lactic and pyruvic acids fell (fig. 2). The levels of these two compounds even seemed inversely proportional to the amount of MCT administered : the more the MCT load rose, the more the levels of lactic and pyruvic acids declined (fig. 3 ).

Furthermore, the pyruvate decrease seemed more pronounced in females than in males of the same age (table 1). A similar phenomenon occurred in obese rats as compared to the controls (table 2), but the changes were not significant, while we obtained divergent results on guinea pigs (table 3). Finally, hepatic MCT catabolism increased the lactate/pyruvate ratio (fig. 2 ; tables 2 and 3 ), a finding that must be considered in relation to the increase in the $\beta$-hydroxybutyrate/acetoacetate ratio observed simultaneously (Bach et al., 1977a). LCT, whose constituent fatty acids are much less oxidized in the liver of non-fasting animals, do not affect these ratios. 
Plasma insulin.

MCT load causes hypoglycemia, but the cause remains to be found. A priori, two types of substances can be suspected of playing a role in this phenomenon : non-esterified fatty acids (NEFA) and ketone bodies.

According to Balasse and Neef (1974) and Seyffert and Madison (1967), NEFA play a major role in glucose metabolism, acting either directly on the liver or indirectly via insulin. If this is true in our study, an LCT load should induce hypoglycemia, since we have established that the ingestion of such fats causes an increase in NEFA (Bach et al., 1977a). On the other hand, MCT should not induce hypoglycemia, since they do not induce changes in plasma concentrations of NEFA (Bach et al., 1977a). Furthermore, it seems that octanoic acid does not stimulate insulin production by rat pancreas in vitro (Pi-Sunyer, 1975 ; Malaisse and Malaisse-Lagae, 1968) in contrast to Sanbar and Martin's earlier findings (1967).

In vivo work in rats (Tidwell and Axelrod, 1948) has demonstrated that ketone bodies have an hypoglycemia-inducing property. Furthermore, Malaisse and MalaisseLagae (1968) have demonstrated that ketone bodies in rat pancreas incubated in vitro could trigger insulin release. Unlike LCT, MCT are highly ketogenic : a MCT load induces a marked and long-lasting hyperketonemia in rats (Bach ef al., 1977a).

Results on the effect of MCT on insulin secretion have been reported in the literature. Hyperinsulinemia was detected after MCT ingestion in humans (Tamir ef al., 1968 ; Pi-Sunyer, Hashim and Van Itallie, 1969) and after perfusion of MCT (Bach et al., 1974) or of sodium octanoate (Sanbar and Martin, 1967) in dogs. On the other hand, no increase in insulinemia was reported in humans ingesting MCT (Bach, 1970 ; McCullough et al., 1971), or in dogs perfused with either MCT (Campbell ef al., 1966) or $\mathrm{C}_{8: 0}$ (Sanbar et al., 1965). The reports on LCT disagree. While they caused hyperinsulinemia in fasting human subjects (Pi-Sunyer, Hashim and Van Itallie, 1969 ; Carroll and Nestel, 1972) and in fasting dogs (Greenough, Crespin and Steinberg, 1967), they had no effect in fasting baboons (Coran, Cryer and Horwitz, 1972).

In agreement with the results of Yeh and Zee (1976), we found an increase of plasma insulin following MCT load. Those authors demonstrated a 180 p. 100 increase in IRI 1 hour after MCT ingestion. Using a much smaller MCT load, we found an increase that was, naturally, smaller (+140 p. 100) but appeared much earlier (5 min. after ingestion). Thus, in mixed blood, hyperinsulinemia always appeared before hypoglycemia, at a time when the plasma level of ketone bodies was close to the maximum (Bach ef al., 1977a). This insulin hypersecretion did not last long and was not present 35 min. after even a high MCT load (Fig. 3).

Intraduodenal perfusion of fat definitively confirmed these results (table 4). MCT induced an increase of NEFA levels in portal blood : the portal pathway of mediumchain fatty acids has been reported by Clément ef al. (1964). Long-chain fatty acids, on the other hand, follow the lymphatic pathway, with the result that NEFA levels remain practically unchanged in portal blood after an LCT load. But the most striking feature in portal blood is the marked increase in IRI after an MCT load.

Post-MCT hypoglycemia thus seemed to be a result of an increase in insulin secretion, probably induced by the high levels of ketone bodies formed during hepatic catabolism of medium-chain fatty acids. Previous failure to demonstrate hyperinsuli- 
nemia might be due to the fact that authors looked for it too long after the beginning of the experiment and, because it represented only a slight increase, it was overlooked owing to hepatic insulinase which prevented its appearance in the peripheral blood.

Reçu en aout 1978.

Accepté en décembre 1978.

Acknowledgements. - We are very grateful to Professor J. Warter for the interest he has taken in this work. We also sincerely thank Mr. Jean Peret for critical reading of the manuscript and Miss Anne Blervaque for skillful technical assistance.

The MCT were kindly provided by the ASTRA-CALVÉ Company. This work was partially supported by the Institut National de la Santé ef de la Recherche Médicale (contract $n^{\circ}$ 76.1.007.7).

Résumé. Une surcharge orale de triglycérides à chaîne moyenne (MCT) (acides gras compris entre $C_{6}$ et $C_{12}$ ) induit chez le rat Wistar nourri normalement une diminution des teneurs plasmatiques en lactate, pyruvate et glucose. Ces variations sont plus nettes chez les femelles que chez les mâles de même âge. Leur intensité est d'autant plus forte que la charge lipidique est plus abondante. La diminution de la glycémie s'observe également chez des rats à jeun. Elle a été mise en évidence chez le cobaye, mais pas chez le rat Zucker.

Cette hypoglycémie est précédée d'une faible augmentation de l'insulinémie.

Les triglycérides à chaîne longue (LCT) (acides gras $>C_{12}$ ) n'ont pas d'action sur les paramètres étudiés.

Il semble que l'hypercétonémie induite par les MCT entraîne une augmentation de la sécrétion d'insuline qui elle, provoque l'hypoglycémie observée.

\section{References}

BACH A., SCHIRARDIN H., BAUER M., WERYHA A., 1977a. Ketogenic response to medium-chain triglyceride load in the rat. J. Nutr., 107, 1863-1870.

BACH A., BAUER M., SCHIRARDIN H., 1977b. Data on lipid metabolism in the genetically obese Zucker rat. Life Sci., 20, 541-550.

BACH A., GUISARD D., METAIS P., MEJEAN L., DEBRY G., 1974. Hypoglycemia induced by medium chain triglycerides. Comp, Biochem. Physiol., 47B, 869-877.

BACH A., 1970. Hypoglycémie après ingestion de graisses à acides gras longs, moyens et courts. Essai d'interprétation métabolique, 295-303. 7th int. Congr. clin. Chem., Geneva/Evian (1969), Karger, Basel.

BALASSE E. O., NEEF M. A., 1974. Operation of the " glucose-fatty acid cycle " during experimental elevations of plasma free fatty acid levels in man. Europ. J. clin. Invest., 4, 247-252.

BATES M. W., LINN L. C., HUEN A. H., 1976. Effects of oleic acid infusion on plasma free fatty acids and blood ketone bodies in the fasting rat. Metabolism, 25, 361-373.

BERGMEYER H. U., BERNT E., SCHMIDT F., STORK H., 1970. D-glucose. Bestimmung mit Hexokinase und Glucose-6-phosphate-Dehydrogenase, 1163-1168. In BERGMEYER H. U., Methoden der enzymatischen Analyse. Verlag Chemie, Weinheim.

CAMPBELL R. G., PI-SUNYER F. X., HASHIM S. A., VAN ITALLIE T. B., 1966. Insulin secretion during octanoate-induced hypoglycemia. Clin. Res., 14, 476.

CARROLL K. F., NESTEL P. J., 1972. Effect of long-chain triglyceride on human insulin secretion. Diabetes, 21, 923-929.

CLÉMENT J., COUREL E., KLEPPING J., BRIET S., 1964. Etude de la répartition chyloportale des acides gras à chaînes courtes et moyennes. Arch. Sci. physiol., 18, 453-467. 
CORAN A. G., CRYER P. E., HORWITZ D. L., 1972. Effect of intravenously administered fat on serum insulin levels. Amer. J. clin. Nutr., 25, 131-134.

CZOK R., LAMPRECHTW., 1970. Pyruvat, Phosphoenolpyruvat und D-glycerat-2-phosphat, $1407-$ 1411. In BERGMEYER H. U., Methoden der enzymatischen Analyse. Verlag Chemie, Weinheim

DEUEL H. J., DAVIS A., 1942. The sexual variation in carbohydrate metabolism. $X$. The comparative glucose tolerance of normal rats and those with fatty acids J. biol. Chem., 146, 649-653.

GREENBERGER N. G., TZAGOURNIS M., GRAVES T. M., 1968. Stimulation of insulin secretion in man by medium chain triglycerides. Metabolism, 17, 796-801.

GREENOUGH W. B., CRESPIN S. R. STEINBERG D., 1967. Hypoglycaemia and hyperinsulinaemia in response to raised free-fatty-acid levels. Lancet, 2, 1334-1336.

GUISARD D., BACH A., DEBRY G., METAIS P., 1972. Mefabolic effects following a short ond medium chain triglycerides load in dogs. II. Influence of the infused fat quantity. Arch. Sci. physiol., 26, 195-205.

HEMS R., ROSS B. D., BERRY M. N., KREBS H. A., 1966. Gluconeogenesis in the perfused rat liver. Biochem. J., 101, 284-292.

HOHORST H. J., 1970. L- (+)-lactat. Bestimmung mit Lactat-Dehydrogenase und NAD, 1425-1429. in BERGMEYER H. U., Methoden der enzymatischen Analyse. Verlag Chemie, Weinheim.

KREBS H. A., PERKINS J. R., 1970. The physiological role of liver alcohol dehydrogenase. Biochem. J. 118, 635-644.

MALAISSE W. J., MALAISSE-LAGAE F. M., 1968. Stimulation of insulin secretion by non-carbohydrate metabolites. J. Lab. clin. Med., 72, 438-448.

MCCULlOUGH F. S., TZAGOURNIS M., GREENBERGER N. J., LINSCHEER W. G., 1971. Stimulation of insulin secretion by medium-chain triglycerides in patients with cirrhosis. GUT, 12, 134-138.

MERIMEE T. J., FINEBERG S. E., 1973. Homeostasis during fasting. II. Hormone substrate differences between men and women. J. clin. Endocr., 37, 698-702.

PI-SUNYER F. X., 1975. Effect of long- and medium chain fatty acids on insulin secretion from pieces of rat pancreas. Proc. Soc. exp. Biol. Med., 149, 693-697.

PI-SUNYER F. X., HASHIM S. A., VAN ITALLIE T. B., 1969. Insulin and ketone responses to ingestion of medium and long-chain triglycerides in man. Diabetes, 18, 96-100.

SANBAR S. S., EVANS J. R., LIN B., HETENYI G., 1967. Further studies on the effect of octanoate on glucose metabolism in dogs. Can. J. Physiol. Pharmacol., 45, 29-38.

SANBAR S. S., MARTIN J. M., 1967. Stimulation by octanoate of insulin release from isolated rat pancreas. Metabolism, 16, 482-489.

SANBAR S. S., HETENYI G., FORBATH N., LIN B. J., EVANS J. R., 1965. Influence of free fatty acid (FFA) on glucose metabolism in vivo and in vitro. Circulation, 32, 11-29.

SEYFFERT W. A., MADISON L. L., 1967. Physiologic effects of metabolic fuels on carbohydrate metabolism I. Acute effects of elevation of plasma free fatty acids on hepatic glucose output, peripheral glucose utilization, serum insulin, and plasma glucagon levels. Diabetes, 16, 765-776.

SOLONI F. G., SARDINA L. C., 1973. Colorimetric microdetermination of free fatty acids. Clin. Chem., 19, 419-424.

TAMIR I., GRANT D. B., FOSBROOKE A. S., SEGALL M. M., LLOYD J. K., 1968. Effects of a single oral load of medium-chain triglyceride on serum lipid and insulin levels in man. J. Lipid Res., 9, 661-666.

TIDWELL H. C., AXELROD H. E., 1948. Blood sugar after injection of aceloacetate. J. biol. Chem., 172, 179-184.

WILLIAMSON D. H., MELLANBY J., KREBS H. A., 1962. Enzymic determination of D-(一)- $\beta$-hydroxybutyric acid and aceloacetic acid in blood. Biochem. J., 82, 90-96.

YEH Y. Y., ZEE P., 1976. Relation of ketosis to metabolic changes induced by acute medium-chain triglyceride feeding in rats. J. Nutr., 106, 58-67.

YORK D. A., STEINKE J., BRAY G. A., 1972. Hyperinsulinemia and insulin resistance in genetically obese rats. Metabolism, 21, 277-284.

ZUCKER L. M., ZUCKER T. F., 1961. Fatty, a new mutation in the rat. J. Heredity, 52, 275-278. 